\title{
John 4:23-24 in North African Preaching
}

\author{
Joseph L. Grabau \\ Katholieke Universiteit Leuven, Belgium \\ joseph.grabau@kuleuven.be
}

\section{Summary}

This paper explores the possibility of recovering a tradition of Donatist readings of John's Gospel, by highlighting five of the so-called Donatist 'anonymous' homilies of the Vienna Collection (Sermones Escorial. 16, 19, 20, 22 and 23; cf. Leroy 1994/1999; Bass 2014/2016; Dossey 2010; and Shaw 2011). After pointing out their relatively limited, threefold Johaninne interest - chapters 4 and 8, and the 'farewell discourse' of chapters 14-17 (Tilley 1997) - I then focus on Sermo Escorial. 16, presenting its exegetical and theological strategies in the light of Donatist ecclesiology and its North African context. Here, I argue that a particular use of John 4:23, in conjunction with a modified form of a wellknown concept of Cyprian (nulla salus extra ecclesiam), stands in sharp opposition to any of Augustine's interpretations of the same verse. Thus, I suggest, Augustine seems both to correct Donatist views of salvation and the church, as well as a Donatist reading of the verse in question. This thesis is to be linked up with other Johannine citations in future research.

\section{Keywords}

Gospel of John - Christian North Africa - biblical interpretation - Augustine of Hippo - Donatism

Biblical citations in ancient North African sources of possible Donatist origin of any kind are for many scholars of special historical and theological interest, not least of all in service of Tilley's project in her book The Bible in Christian North Africa, where she sought to explore the specific contours of biblical interpretation unique to Donatist authors in the fourth century, within the broader tradition of North African exegesis, ecclesiology, and socio-political 
eschatology. ${ }^{1}$ The broader thesis of my current project is that because Augustine of Hippo happened to spend his effort in crafting arguments and interpretations of the Johannine text for a number of his earliest homilies In Iohannis euangelium tractatus, he might have had in mind a particular tradition of Donatist interpretations of John, which he sought to correct. This thesis benefitted from the recent work on the anti-Donatist sermons of Augustine by Adam Ployd, a student of Lewis Ayres, who convincingly discovered much about the Trinity in the same tractates, suggesting that Augustine brought together proNicene and anti-Donatist argumentation in a synthetic whole. ${ }^{2}$

Yet it may be fair to say that Ployd's interest was more in Augustine's trinitarian and anti-Donatist rhetoric and polemic, rather than how and why Augustine sought to approach John as a whole, or how Augustine's early interpretation of John fits into his overarching approach to any biblical author. Why, of all books in the Bible, would Augustine have been drawn to John, rather than - for example, Song of Songs - in creating the early stages of an anti-Donatist commentary? That verses from Song of Songs were common in North African views of the church is well-attested, and a topic dealt with at length in another recent book from Karl Shuve. ${ }^{3}$ Since the days of Cyprian, authors loved to quote the description of the bride as a "garden enclosed, a sealed fountain" (Song 4:12). But were texts from the Gospel of John as common in the fourth century, either in pro- or anti-Donatist preaching and polemic? And what role did such Johannine citations have in constructing and maintaining Donatist communities? How did John contribute to Donatist and other North African pastoral theology?

To answer this research question, I propose here to re-examine a selection of homilies that circulated in North Africa during the early fifth century. Although the Donatist origin of this collection is disputed by scholars, its late antique and North African origin seems secure. By holding up patterns of Johannine citation that emerge within this set of short pastoral sermons, I aim to suggest points of contact and discontinuity with Augustinian exegesis, in such brief fashion as the current format will permit.

1 See especially M.A. Tilley, The Bible in Christian North Africa: The Donatist World, Minneapolis, 1997, which is supported by numerous other journal articles and book chapters.

2 A. Ployd, Augustine, the Trinity, and the Church: A Reading of the Anti-Donatist Sermons (оsнт), Oxford, 2015

3 K. Shuve, The Song of Songs and the Fashioning of Identity in Early Latin Christianity (oECS), Oxford, 2016. 
Sermo 37 (W37 = Sermo Escorial. 16 or E16), is one of at least five homilies rather too short to be properly called sermons - in the anonymous Vienna Collection that directly cites from the fourth gospel. ${ }^{4}$ In late medieval and Renaissance manuscripts, the author of this particular text was believed to be the great preacher and archbishop of Constantinople, St John Chrysostom, whose words had been (presumably) translated for a Latin audience. Until the late twentieth century, of the sixty homilies contained in this anonymous 'Donatist' corpus, twenty-three shared this attribution. By the late nineteenth century, however, G. Morin had already cast doubt on their Chrysostomic authorship, first supposing a sixth-century Greek author, and later (as I understand) identifying an anonymous preacher - known alternatively as 'pseudoChrysostom' or the 'Latin Chrysostom' - as their true author. ${ }^{5}$ Thereafter, A. Wilmart gave multiple critiques of the former's conclusions, insisting the origin was southern Italy in the later fifth century, and presumably thus a native speaker of Latin. ${ }^{6}$ In so doing, Wilmart succeeded in reducing the overall number of texts thought to be Chrysostom's, so that by 1967 with the release of

4 The convention of B. Shaw, in his study Sacred Violence: African Christians and Sectarian Hatred in the Age of Augustine, Cambridge, 2011, is to cite the homilies of this collection using the 'Vienna' numbering of Leroy (1999), yet to preserve the name 'Escorial'-after the original manuscript discovered in Spain, which included only twenty-eight of the now-accepted total of sixty. L. Dossey, Peasant and Empire in Christian North Africa (тСн, 47), Berkeley, 2010, follows the same ennumeration, yet refers to individual homilies with the short-hand, 'Anon. H. Esc.', following the precedent of R. Gryson, Répertoire général des auteurs ecclésiastiques latins de l'antiquité et du haut Moyen Âge, 2 vols (Vetus Latina: Die Reste der Altlateinischen Bibel, 1/1, Freiburg, 2007.

5 G. Morin, "Étude sur une série de discours d'un évêque [de Naples?] du vie siècle," RBen, 11 (1894), pp. 385-402; G. Morin, "Un essai d'autocritique: Série de discours d'un évêque du ve-VI siècle," RBen, 12 (1895), pp. 385-390, at pp. 390-391; G. Morin, "Les expériences d'un travailleur dans le domaine de la littérature chrétienne: Conférence donnée à Louvain le Mardi 6 Février 1900 (1), RHE, 1 (1900), pp. 66-84; G. Morin, "De la Besogne pour les jeunes, sujets de travaux sur la littérature latine du moyen âge. Conférence donnée au Séminaire historique de l'Université de Louvain, le Jeudi 16 Février 1905," RHE, 6 (1905), pp. 327-345; and G. Morin, Études, textes et décourvertes (Anecdota Maredsolana, Série 2, vol. 1), Maredsous, 1913. See J.P. Bouhot, "La collection homilétique pseudo-chrysostomienne découverte par Dom Morin," REAug, 16 (1970), pp. 139-146, at pp. 139-140.

6 A. Wilmart, La collection des 38 homélies de Saint Jean Chrysostome," JTS, 19 (1917-1918), pp. 305-327. 
volume four in the PLS series, one finds twenty-seven in total, known as the Collectio Escurialensis. ${ }^{7}$

The debate concerning authorship continued in the late 196os and thereafter. ${ }^{8}$ It was not until the efforts of F.-J. Leroy in the 1990s that this line of scholarship met with the field of Donatist and North African studies, already growing since the turn of the century thanks to the work of P. Monceaux, W.H.C Frend, P. Brown, and M. Tilley. ${ }^{9}$ After the sixty homilies, previously identified as authored by pseudo-Augustine, pseudo-Fulgentius, the Latin Chrysostom, or another anonymous homilist, were found at the Austrian National Library in a single manuscript (Wien, Österreichische Nationalbibliothek, lat. 4147), Leroy opened the door to a Donatist interpretation of the corpus as a single entity. ${ }^{10}$ Based on Sermo 39 (W39/E18), in which the homilist describes

7 Patrologiae Latinae Supplementum, 4, ed. by P. Hamman, Turnhout, 1967, cols. 689-740 (numbered 2 to 28). See A.L. Bass, "An Example of Pelagian Exegesis in the Donatist Vienna Homilies (Ö.N.B. lat. 4147)," in: The Uniquely African Controversy: Studies on Donatist Christianity, ed. by A. Dupont, M.A. Gaumer, and M. Lamberigts, (LAHr, 9), Leuven, 2015, pp. 197-209, at p. 199. Regarding the anonymous Vienna Collection's 'homogeneity', as the last author points out see also G. Morin, "Les sources non identifiées de l'homéliare de Paul Diacre," RBen, 15 (1898), pp. 400-403.

8 B. Altaner, "Altlateinische Ubersetzungen von Chrysostomusschriften," in: Kleine Patristische Schriften, by B. Altaner (TU, 83), Berlin, 1967, pp. 416-436. For subsequent advances, which aim to identify the author (or translator?) as the early fifth-century deacon Annianus see e.g., F. Schlatter, "The Author of the Opus Imperfectum in Matthaeum," vc, 42 (1988), pp. 364-375, at p. 369; and M. Gorman, "Annianus of Ceneda and the Latin Translations of John Chrysostom's Homilies on the Gospel of Matthew," RBen, 122 (2016), pp. 100124.

$9 \quad$ F.-J. Leroy, "Vingt-deux homélies africaines nouvelles attribuables à l'un des anonymes du Chrysostome latin (PLS 4) (Vienne Ö.N.B. Ms. Lat. 4147)," RBen, 104 (1994), pp. 123-147; F.-J. Leroy, "L'homélie donatiste ignorée du corpus escorial (Chrysostomus Latinus, PLS IV, sermon 18)," RBen, 107 (1997), pp. 250-262; F.-J. Leroy, "Les 22 inédits de la catéchèse donatiste de Vienne: Une édition provisoire," RecAug, $3^{1}$ (1999), pp. 149-234; and F.-J. Leroy, "Compléments et retouches à la $3^{\mathrm{e}}$ édition de la Clavis Patrum Latinorum. L'homilétique africaine masquée sous le Chrysostomus latinus, Sévérien de Céramussa et la catéchèse donatiste de Vienne," RHE, 99 (2004), pp. 425-434. For Donatist studies see P. Monceaux, Histoire littéraire de l'Afrique chrétienne depuis les origines jusqu'à l'invasion arabe, 7 vols, Paris , 1901-1923; W.H.C. Frend, The Donatist Church: A Movement of Protest in North Africa, Oxford, 1952; P. Brown, Augustine of Hippo: A Biography, Berkeley-Los Angeles, 200o, rev. edn; Tilley, The Bible in Christian North Africa; M.A. Tilley, "Redefining Donatism," AugSt, 42 (2011), pp. 21-32; and the chapters of The Uniquely African Controversy.

10 Though J.-P. Bouhot is credited with the 'discovery' of this manuscript in the 1980s, at the Austrian National Library of Vienna, it was the work of F. Leroy to advance speculation about their Donatist character; see. A. Bass, "Dissident Preaching in Africa: Inherently 
certain false Christians as traditores - the famous moniker in the early fourth century for followers of Caecilian among those of Donatus - among several other observations, Leroy concluded the author must have been a 'Donatist', writing in the early to mid-fifth century. Since his numerous published articles on the collection, scholars now also debate this attribution - with arguments both for and against. ${ }^{11}$

Why, one might ask, should Johannine citations found in an anonymous collection of ancient Christian sermons be of any special significance? Ultimately, if any number of the homilies in the series is indeed demonstrably North African in origin, and datable to the fifth century, then a synthetic investigation of those theological and exegetical strategies at work may contribute to an overall picture of preaching and polemics during the era of Donatism and its refutation. In short, the indexing of John's Gospel in relation to the Donatist controversy turns largely upon Augustine of Hippo's early anti-Donatist In Iohannis euangelium tractatus, which have appropriately received recent scholarly attention. ${ }^{12}$ What has yet to come to light, however, is a global picture of preaching on the fourth gospel in the history of Christianity in North Africa, one that might take into account both Augustine's relevant tractates, as well as the work of his near-contemporaries. After all, since the days of Cyprian, North African authors loved to quote the description of the bride as a "garden enclosed, a sealed fountain" (Song 4:12) in sermons and polemical refutations of their opponents. ${ }^{13}$ Were texts from the Gospel of John as common in the fourth

Violent?," p. 4, which is to be published in a forthcoming volume of essays edited by J. Merdinger.

For: J. Alexander, “Criteria for Discerning Donatist Sermons," in: Studia Patristica, 38, ed. by M.F. Wiles and E.J. Yarnold, papers presented at the Thirteenth International Conference on Patristic Studies at Oxford 1999, Leuven, 2001, pp. 3-7; A.L. Bass, "Fifth-Century Donatist Catechesis: An Introduction to the Vienna Sermon Collection, Ö.N.B. M. Lat. 4147," Ph.D. diss., Saint Louis University, 2014; see also Brown, Augustine of Hippo, p. 486; W.H.C. Frend, "Donatus paene totam Africam decepit. How?" JEH, 48 (1997), pp. 611-627, at p. 619, n. 65; Dossey, Peasant and Empire, p. 165; Shaw, Sacred Violence, p. 846. Against: F.-J. Dolbeau, "Sermons 'africains': critères de localisation et exemple des sermons pour l'Ascension," in: Ministerium Sermonis III, ed. by A. Dupont, Turnhout, forthcoming. In relation to Nicene trinitarianism see Ployd, Augustine, the Trinity, and the Church.

13 Quoted, for example, in the third century by Cyprian of Carthage, Ep. 69.2.1; Sancti Cypriani episcopi Epistularium, pars III, 2, ed. by G.F. Diercks (CCL, ${ }_{3}$ C), pp. 471-472, as well as 
century, either in pro- or anti-Donatist preaching and polemic? What role did such Johannine citations have in constructing and maintaining communities in Christian North African? How did John contribute to Donatist and other North African pastoral theology?

In terms of Johannine citations, therefore, it turns out the collection once ascribed to John Chrysostom is remarkable for its apparent consistency of the passages chosen - from three distinct places in John's gospel: (1) John 4, in which Jesus famously speaks with the Samaritan woman at Jacob's well (two direct citations, of one verse each [John 4:23 and 34]); (2) John 8, in which Jesus now engages with a hostile Jewish audience on what it truly means to be the progeny of Abraham (three direct citations, also of one verse each [John 8:34, 39, and 56]); and (3) by extension, the entire set of three (or four) chapters that make up the so-called 'farewell discourses' (John 14-16, and the Prayer of Jesus in John 17) (seven direct citations, two of which contain more than one verse [John 14:6, 15; 15:14, 14-15, 19-20; 16:20; and 17:24]). In addition, 1 John - which I will not consider at length - also appears at least twice, though only once in a direct citation (1 John 2:6; 3:4 and 8). Below, I will consider these three sets, for reasons that will become clear, in reverse order.

In the remainder of the anonymous Vienna Collection, which were not previously attributed to the Latin Chrysostom to my knowledge, an additional sixteen direct citations occur; and of these, the first repeats a verse from John 8:56; four others are taken from the same chapters 14 and 15 (John 14:12, 15, and 27; 15:14) - two of which also share identical verses - plus a last, also from the farewell discourse in John 16:20. The most commonly cited verse in the entire anonymous Vienna Collection is, in fact, John 5:14, in which Jesus instructs the man just healed to "sin no more, now that you have been made whole", and this verse appears as a direct citation in five of the homilies - one of which, Sermo $5^{2}$ (W $\left.5_{5} / \mathrm{E} 25\right)$, was attributed to the Latin Chrysostom. ${ }^{14}$ In addition to these verses, a remarkable low number of 'outlying' Johannine citations remain to be mentioned - four from the gospel (John 5:20; 6:20; 7:32; and 18:14), and a fifth from the first letter (1 John 3:15). So it seems the entire collection, including the

Parmenian and Optatus in the fourth century. See Shuve, The Song of Songs and the Fashioning of Identity in Early Latin Christianity, pp. 24-27 for extended discussion, and cf. S. Lancel, St Augustine, trans. A Nevill, London, 2002, Eng. edn, pp. 281-282.

14 Although editors correctly and repeatedly identify the entire phrase, "ecce sanus factus es; iam noli peccare, ne deterius tibi aliquid contingat," as a citation of the Latin text for John 5:14, the concept and precise Latin phrasing of "iam noli peccare" occur also at John 8:11. Augustine cites both Johannine verses equally in his corpus - as well as the similar use of "irascimini, et nolite peccare" of Ps 4:5 on less frequent occasions. 
texts attributed to the Latin Chrysostom, shares a common interest in the three isolated Johannine passages I have highlighted.

Even on the surface, one might easily suppose why these 'epicenters' were of interest. In reverse order: the 'farewell discourse' (John 14-16 and 17) delivered within an inner sanctum, where on the night before the crucifixion, the disciples received a moment of communion and instruction about the coming days. Most conspicuous at that moment was the absence of Judas, who was to betray Christ, at this time of such importance. As Tilley writes, "Judas had been gone from the upper room when Jesus washed the feet of the apostles. He alone of the inner circle was not clean", ${ }^{15}$ and as she goes on to point out at length, in fourth-century North Africa Judas had become a type used in Donatist polemics, against their Catholic opponents: "true Christians were clothed in Christ at Baptism, Catholics were clothed in Judas." Indeed, the Latin word that described his betrayal, traditor, was the very term of contempt spoken against Caecilian's followers among the Donatists and a key piece of evidence in the more recent attribution of the collection by Leroy and those who followed, outlined above.

\section{John in the Homilies of the Vienna Collection}

\subsection{The Use of John 14:15; 15:14 and 20}

First, in Sermo 5 ( $\left.\mathrm{W}_{5} / \mathrm{E}_{3}\right)$ on the so-called 'proto-euangelion' of Genesis 3:15, and the failure of our first parents to hold to the divine command, the author cites John 14:15, "if you love me, says the Lord, keep my commands" (mea praecepta seruate). ${ }^{16}$ The emphasis on God's commands in Genesis (praecepta obseruanda domini, which are also called Imperatoris uoluntatem, iussa coelstia, interdictum domini) is to see them in unbroken continuity with the commands of Jesus (mea praecepta). The call is thus to remind the listener of his or her instruction, and to challenge the audience to hold fast to the legal prescriptions of the Lord, while waging a battle against evil (certamen atrox, magnum bellum). Here, the contrast with the 'world' emerges, as the author recalls how mother church is constantly waging this war through her martyrs and confessors. The picture is one of rather strict moral expectation, joined with an apparent division between the church and the 'world', although this is not explicitly stated.

15 Tilley, Bible in Christian North Africa, p. 168.

16 Anon. Sermo Escorial. 3; PLS, 4.673. 
In Sermones 43 (W43/E22) and 44 (W44/E23), the author takes up a verse from John 15, "you are my friends, if you do what I command" (John 15:14). The moral tone is the same, that of divine law followed by human obedience. Much of the prescriptive language repeats here, and again the laws given long ago in Genesis stand in direct line with those of Jesus. Indeed, the apostles were like Abraham, who obeyed the divine commands and precepts (caelestia praecepta). ${ }^{17}$ The second, Sermo 44, sensibly adds a text from John's first letter, "whoever claims to dwell in Christ ought to walk as he did" (1 John 2:6). The very 'laws of friendship' (iura amicitiae) require this obedience. ${ }^{18}$

Finally, in Sermo 46 (W46/E24), the author speaks to the theme of martyrdom, especially in relation to exemplary heroes of the faith in the bible. "If they persecuted me, they will also persecute you ... because you are not of the world, and I have chosen you from the world, the world for that reason hates you" (John 15:20 and 19). ${ }^{19}$ Here, the division of the faithful from the world becomes more openly given, and this is one example of how Johannine conceptual language does influence the homilist's theme; and vice versa, how the homilist has chosen a particular 'proof text' in order to support what is apparently a 'Donatist', North African position.

\subsection{The Use of John 8:12 and 8:31-32}

The context of John 8 is, in general, a confrontation between Jesus and what seems to be an unspecified Jewish audience. Jesus is claiming to be sent from the Father as the light of the world (John 8:12), and says that only by 'remaining in my word' will you "truly be my disciples, and you will know the truth, and the truth will set you free" (John 8:31-32). The audience responds by claiming that Abraham was their father, and they have never been enslaved (John 8:33). The homilist uses this passage first in a discussion of Zacchaeus, who in Luke's gospel climbed a tree better to see Jesus, decided to give away his wealth, and was called a "true son of Abraham" (Luke 19:9). In Sermo 40 (W4o/E19), the homilist understands this statement to mean that Zacchaeus wanted to see the Lord, just as Abraham had - "he saw it and was glad" (John 8:56) - , and both men responded with the same obedience. Thus, action is what makes one a 'child of Abraham', as the previous verse had said, "If you were children of Abraham, you would do the good deeds of your father" (John 8:39). ${ }^{20}$ In Sermo

\footnotetext{
17 Anon. Sermo Escorial. 22; PLS, 4.720-722.

18 Anon. Sermo Escorial. 23, PLS, 4.724: "Non potest ad familiaritatem Christi accedere, qui eius mandata noluerit obseruare. Adeptio amicitiarum est obseruatio mandatorum."

19 Anon. Sermo Escorial. 24; PLS, 4.728.

20 Anon. Sermo Escorial. 19; PLS, 4.712.
} 
$30\left(\mathrm{~W}_{30} / \mathrm{E}_{15}\right)$, the concern is again on obedience to the law, where much of the same vocabulary reoccurs (imperata, iussa, and praecepta) in a discussion of sin and legal penalty, with reference to the saying, "he who sins, is a slave to sin" (John 8:34; cf. 1 John 3:4 and 8). ${ }^{21}$ Finally, in a text already mentioned above, Sermo 43, the author again highlights Abraham as the example of obedience, which is then connected to the discussion in John 8 (John 8:58). The sense is, to be a true child of Abraham, one must hold fast to the 'rules of friendship': “... mandatorum obseruatio, amicitiae est confirmatio."22

\subsection{The Use of John 4:23 (and 4:34)}

Finally, we come to John 4, in which the concern is (in part) the distinction between Jews and Samaritans, and the inherent notion of differing religious practice between these two groups. For, as the biblical text reads, "the hour is coming, and is now here, when true worshipers will worship the Father in Spirit and truth" (John 4:23). This verse is cited directly in Sermo 37 (W37/E16), with a noteworthy Donatist interpretation, which I would like to explore below. A second citation from the same chapter also occurs in Sermo 41 (W41/E20), in which the author mentions Christ's saying, "my food, and my drink, are to do the will of the one who sent me" (John 4:34) ${ }^{23}$ The call here is to produce the fruit of good works and obedience, so that when the Lord comes, he may find his 'fig tree' filled with good fruit. ${ }^{24}$ For, "the Lord does not allow unproductive trees to stand in his vineyard." 25 The well-instructed (instructum) believer will, instead, always be prepared. This form of moral exhortation is in keeping with much of the anonymous Vienna Collection, as I have tried to show here. In addition, reference to 'the world' (saeculum, mundus) occurs at least five times, in conjunction with language of punishment (poena), judgement (iudicium), and duty (officia). In a 'dark' world, the precepts of the Lord (praecepta) are the only sure path that leads to life (Ps 1:3). ${ }^{26}$

While such a contrast does not make use of the word 'church' (ecclesia), nor even to appear to be making a claim about being the 'true church', Sermo 37 dwells at some length on this concern. Most notably, in commenting on John 4:23, "the hour will come, when true worshipers will worship the Father in

\footnotetext{
21 Anon. Sermo Escorial. 15; PLS, 4.703.

22 Anon. Sermo Escorial. 22; PLS, 4.722.

23 Anon. Sermo Escorial. 20; PLS, 4.714.

24 Anon. Sermo Escorial. 20; PLS, 4.717.

25 Anon. Sermo Escorial. 20; PLS, 4.714: "Non es arbor a deo plantata, si bonos fructus non exhibes."

26 Anon. Sermo Escorial. 20; PLS, 4.714.
} 
Spirit and truth", the homilist lifts and adapts a saying from Cyprian, on the nature of the 'true church'. Cyprian had famously prescribed a view of the church, summarized by the slogan, "salus extra ecclesia non est", which he used on at least one occasion himself. ${ }^{27}$ Because of the North African heritage of this phrase, and the 'rigorist ecclesiology' it represents, therefore, Sermo 37 merits a careful reading, in light of the other citations of Cyprian in what became his legacy.

The homily begins with an exhortation to continue in the Christian way of life, to continue in prayer, to give praise to God, to preach of his many mighty deeds, and to worship him with great devotion. ${ }^{28}$ By so doing, the people of God both fulfill their duty (nostra officia compleamus), and proclaim his power to the nations. ${ }^{29}$ Moreover, such obligations of Christian life serve to distinguish the homilist's ecclesia from all false believers - presumably, the 'false' Christians in the Catholic Church. The true and the false, in any circumstance, the homilist explains, cannot be joined together; they are of two separate natures. "Truth does not accept falsehood, just as sweetness does not leave room for any bitter flavor (or joy any room for sorrow); night and day are separate things; the 'cold' does not mix well with heat." 30 When either of these opposites meets the other, one of them is destroyed, as a fact of nature.

Thus, with the apostle Paul, the homilist reminds his audience not to be joined with 'unbelievers' (infidelibus), for "What share does justice have with iniquity? Or what concord exists between Christ and a demon?" (2 Cor 6:14). Truth is God's, and falsehood the devil's, with the result that one must, as a Christian, "... hope in the church, in order to be found worthy to receive the Holy Spirit, and to remain acceptable for the sacred mysteries (sanctis

27 See, in particular, Cyprian Ep. 73.21.2, CCL, 3 C.555. For additional scholarship on Cyprian of Carthage, including his ecclesiology and the treatment of salvation outside of the church, see especially: M. Bévenot, "Épiscopat et Primauté chez S. Cyprien," ETL, 42 (1966), pp. 176-195; M. Fahey, Cyprian and the Bible: A Study in Third-Century Exegesis, Tübingen, 1971; J.P. Burns, Cyprian the Bishop , London, 2002, p. 120; G.D. Dunn, "Heresy and Schism According to Cyprian of Carthage," JTS, n.s. 55 (2004), pp. 551-574; G.D. Dunn, Cyprian and the Bishops of Rome: Questions of Papal Primacy in the Early Church, (ECS, 11) Strathfield, NSw, 2007, p. 157; and A. Brent, Cyprian and Roman Carthage, Cambridge, 2010, p. 303. On Cyprian's relation to Augustine of Hippo, see also most recently M.A. Gaumer, Augustine's Cyprian: Authority in Roman Africa (Brill's Series in Church History and Religious Culture, 73), Leiden, 2016.

28 Anon. Sermo Escorial. 16; PLS, 4. 705.

29 Anon. Sermo Escorial. 16; PLS, 4.705-706.

$30 \quad$ Anon. Sermo Escorial. 16; PLS, 4.706: "Falsum enim ueritas non capit, amaritudinem dulcedo non patitur: noctes et dies diuersae sunt, frigus calori non conuenit.” 
actibus)...."31 This was "so that as a follower of the truth (sectator ueritatis), the Christian may worship God in Spirit and truth." ${ }^{2}$ This mention of sanctis actibus, which I have translated as 'sacred mysteries', seems to suggest what Peter Brown had in mind when describing typical Donatist preference for "ritual purity that stemmed straight from the Old Testament ... [that confers] the fear of a sudden loss of spiritual potency."33

In warning against those false believers (quosdam falsos adoratores), the speaker then remarks, in a telling phrase, "truth does not exist outside of the church, because the truth is Christ, who said, 'I am the way, the truth, and the life' [John 14:6]. Therefore, if truth does not exist outside of the church, it must of necessity be founded within the church (in ecclesia)." ${ }^{44}$ The wording does not precisely follow Cyprian's nulla salus as it is most well-known; however, the use of extra ecclesiam in such a way surely must recall the North African tradition. ${ }^{35}$ Around the 'true' church is a clear boundary, and outside of it, there is no 'salvation' (nulla salus) - or here, no truth (ueritas non est).

Here, ueritas does not simply replace salus with a different concept; 'truth' is, rather, in this context co-extensive with 'salvation', linked in a chain in which one implies the other, just as Christ - who exists only "in the church" (in ecclesia) - himself implies the (presence of the) Holy Spirit. The moral exhortation then follows. For, if the Holy Spirit is not to be found outside of the church which has been gifted with God's favour through Christ our Lord, then one must hope in the (true) church, "in order to be counted worthy to receive the Holy Spirit."36 Thus, "by a holy way of life, one may hold fast to the Spirit, and remain able to worship God among the true believers" (inter ueros adoratores). ${ }^{37}$ In short, a person's actions will declare oneself a "rebel against the truth ... who supposes that he (or she) ought to despise the precepts of God (praecepta

$31 \quad$ Anon. Sermo Escorial. 16; PLS, 4.706-707: “... in ecclesia Christianus exoptet, ut sanctum spiritum mereatur accipere: et acceptum sanctis actibus retinere ..." Anon. Sermo Escorial. 16; PLS, 4.706: “... ut christianus ueritatis sectator in spiritu et ueritate deum adoret ...

33 Brown, Augustine of Hippo, p. 214.

34 Anon. Sermo Escorial. 16; PLS, 4.706: “... ueritas extra ecclesia non est: quia ueritas Christus: Ego sum, inquit, uia, ueritas, et uita. Ergo si ueritas extra ecclesiam non est: in ecclesia sit constituta, necesse est."

Variations on the concept are to be found within Cyprian's own writing, the most literal expression being that of Ep. 73.21.2, "salus extra ecclesiam non est"; to which, having cited, Augustine De bapt. 4.17.24; NBA, 15/1.422, responds, "quis negat?"

36 Anon. Sermo Escorial. 16; PLS, 4.706: “... ut sanctum spiritum mereature acciper ...

37 Anon. Sermo Escorial. 16; PLS, 4.707: “... ut inter ueros adoratores et ipse possit deum adorare." 
dei)."38 As elsewhere in the collection, legal language emerges as a trademark element: diuina iussa, obsequia, and poena. Failure of duty to the divine commands leads to the just penalty - which is outside the church.

It is easy to see why, on such a moral landscape, the reference to John 5:14 "stop sinning now that you have been made well, lest something worse happen" - should occur so frequently in the anonymous Vienna Collection. For this author, once a 'true' believer has joined the 'true' church of Christ, he (or she) ought to put aside all sin, and to lead a morally pure life. The church is a place of the elect, those who obey the law:

When you show your hand, or reveal your heart, lift your face to the sky, turn your eyes heavenward - do you not show your whole self to the Maker, our Lord? Happy hands are clean, blessed indeed is a pure heart; glorious is your face when it shines with integrity; eyes are dignified if they are not spoiled by concupiscence; in short, the whole man is happy, if the whole is without disgrace. ${ }^{39}$

Thus, in Sermo 37 the moral dimension and the exclusionary rhetoric are put to the same purpose, of what Tilley has called 'world-constructing' and 'worldmaintenance'. Although the author of this last homily does not name any individuals, or even 'Catholics' in general, it seems this sort of construction and maintenance is taking place. In my opinion, the personality of Augustine himself, or the leadership policies of the state-sponsored Catholic Church, might have been at issue. In any case, the elements I have highlighted in other homilies, which resurface again here, serve to promote the same characterization of the Donatist Church under pressure that scholarship has long wrestled to define with faithfulness and precision.

Finally, although baptism (or re-baptism) is not a major concern on the surface level in Sermo 37, one easily may be convinced that the moralism and exclusivity of the homilist are in fact directed against the practice of Catholic baptism, as well as the very existence of a rival church in North Africa. The emphasis here on the restricted freedom of an individual to observe his or her

38 Anon. Sermo Escorial. 16; PLS, 4.707: “... ueritatis rebellem ... qui putauerit praecepta dei debere contemni."

39 Anon. Sermo Escorial. 16; PLS, 4.707: "Nonne cum ostendis manus, aperis pectus, faciem erigis ad caelum, oculos attolis, totum te domino creatori ostendis? Denique foelices manus si mundae sunt: beatum pectus, si purum est: gloriosa facies, si simplicitate resplendent: digni oculi si concupiscentia non fuerint maculate: foelix totus homo, si totus fuerit illibatus." 
faith among the 'true believers' (ueriadoratores) in fact suggests the practice of exclusion from eucharistic sharing or other forms of sacramental communion. While no sacrament is indicated, there is talk of 'sacred actions' (actus sancti) - and the suggestion of a juridical status that joins the 'true believers' together. Indeed, the homilist says, "access to God is nearly impossible, once contempt of the divine command precedes ... for just as acts of devotion lead to greater blessing, so too contempt of God's will leads only to punishment." 40

\section{$4 \quad$ Augustine's Preaching on John 4:23-24}

In turning to Augustine, my concern will be to indicate first how his own reading of the same verse was in fact significantly unlike that of the anonymous homilist above. He does not land so much upon the issue of truth (ueritas) in this verse, but rather on the word - Spirit, which he finds in the subsequent verse: "God is Spirit" (John 4:24), for which I will present evidence from various Augustinian sermons. In short, I believe this contrast likely confirms points of difference between Augustinian exegesis and ecclesiology, compared with that of the Donatists; yet it also reaffirms my suggestion that both contributed to and operated within the same theological environment of North Africa. Of course, Augustine would go on to make use of Cyprian and even the particular quotation reference above, though I will stop short here of exploring that terrain in any great detail.

\subsection{Augustine's In Io. eu. tr. 15}

When Augustine delivered his In Iohannis euangelium tractatus, he considered the same verse on one particular occasion in the fifteenth tractate, and it may be surprising how sharply his take on this verse differs, in light of the Donatist controversy he was facing at the time. Delivered in $c .407$, In Iohannis euangelium tractatus 15 does make a point to disagree with the Donatist view of the sacraments, as if baptism and eucharist were to be found outside the Catholic Church. ${ }^{41}$ Yet with John 4:23, Augustine prefers to take a more principled, Pau-

40 Anon. Sermo Escorial. 16; PLS, 4.707: "Difficilis est enim ad impetrandum aditus, cum praecedit iussionis diuinae contemptus ... Vt enim obsequia pariunt beneficia, sic contemptus exhibet poenam."

Augustine Io. eu. tr. 15.8; Sancti Aurelii Augustini In Iohannis Euangelium Tractatus CXXIV, ed. by R. Willems (CCL, 36), Turnhout, 1954, p. 153 [= NBA, 24/1.352]. For recent English translation see The Works of Saint Augustine: A Translation for the 21st Century [= WSA], part I, vol. 12: Homilies on the Gospel of John, trans. E. Hill, Hyde Park, NY, 2009. 
line approach to the verse - rather than engage in the sort of polemics outlined above, of testing and defining the boundaries of the 'true church'. Augustine's interest is, instead, on the Spirit, and he connects John 4:23, on the need to worship the Father "in spirit and truth" ("in spiritu et ueritate"), with John 4:24"God is Spirit" ("spiritus est Deus"). "Why does the Father seek those who worship him, not on the mountain or in the temple but 'in spirit and in truth'? 'God is Spirit' (John 4:24). If God were a body, it would have been right for him to be worshiped on the mountain, because a mountain is also a body; and so, it would have been right for him to be worshiped in the temple, since a temple too is physical." ${ }^{2}$

This is Augustine's first explanation. He expands by looking to the previous verses (John 4:22-23), on the Jewish and Samaritan peoples and their need to worship at God's temple on the mountain. However, not once in this context does Augustine openly turn the passage against the Donatists. Rather than emphasis on being 'in the truth', St Augustine thus prefers to acknowledge the importance of worship 'in the Spirit' - for God is not a physical body (a point of emphasis that maybeunderstood as a relic of hisanti-Manichean polemics) ${ }^{43}$

\subsection{A Survey of the Similar Evidence}

In his enarratio on Psalm 130, Augustine speaks of the body of Christ as the temple of God (1 Cor 3:17), which is made up of all believers in the whole world. ${ }^{44}$ Thus, all who pray in this 'temple' will be heard, for the body of Christ prays "in spiritu et ueritate" (John 4:23). Those outside the temple of God's people are not so much 'false believers' as simply un-believers, who have sought their own designs ("sua quaerentes, non quae Iesu Christi"). Most importantly, however, Augustine again emphasizes the need for prayer in the Spirit (En. Ps. 130.3), for God's temple is not the physical temple, built by human hands, which one day will fall. Yet, though he does speak of the ecclesia catholica, Augustine here does not emphasize its veracity (uera ecclesia), de-

42 Augustine, In Io. eu. tr. 15.24; NBA, 24/1.368: "Quare Pater tales quaerit qui adorent eum, non in monte, non in templo, sed in spiritu et ueritate? Spiritus est Deus. Si corpus esset Deus, oportebat eum adorari in monte, quia corporeus est mons; oportebat eum adorari in templo, quia corporeum est templum."

For a similar reading of John 4:22-24, see Augustine, En. Ps. 130.1-4; Sancti Aurelii Augustini enarrationes in Psalmos CI-CL, ed. by E. Dekkers and J. Fraipont (CCL, 40), Turnhout, 1956, pp. 1898-19oo [= NBA, 28/1.238-244]. For recent English translation see WSA, part III, vol. 20: Expositions of the Psalms: 121-150, trans. M. Boulding, Hyde Park, NY, 2004.

44 Augustine, En. Ps. 130.1; NBA, 28/1.240: “... corpus Christi constat ex multis credentibus in toto orbe terrarium ..." 
spite the clear and direct link to John 4:23. Rather, he turns to speak of the one voice of the church that sings in the psalm (totus Christus).

On Psalm 63, in another sermon, Augustine again presents a similar contrast. According to the text of the Psalm, the just man will delight in the Lord and hope in him; and Augustine remarks that so, also, does the church place her trust in God, especially in the sacraments. ${ }^{45}$ Yet worship of God must go beyond the limitations of physicality, for "God is Spirit" and therefore, "those who worship him, ought to worship in spirit and in truth" (John 4:24). Here, Augustine omits the exclusion introduced in the gospel text, and he does not quote the line about 'true worshippers' (ueri adoratores). Does this fact not seem to be another instance of pastoral generosity and tactful quotation of the Scriptures? God is not physical, so the argument runs, and thus he need not be worshipped in this or that physical place: that is enough for Augustine, here. He then goes on to quote from John's first letter, "God is love" (1 John 4:8), and to speak of this love as "ineffable goodness, beneficent goodness, the good Creator of all good things." ${ }^{46}$ Clearly, his interest is placed differently.

In two last sermons, the same phenomenon occurs. In the augmented version of Sermo 198, the more complete version of which is part of the Dolbeau discoveries, Augustine makes similar assertions, saying that, "one who prays well, prays interiorly." ${ }^{77} \mathrm{He}$ then cites from John 4:21-23, in order to demonstrate this very point. "Go to the church," he says, "in order to excite your fervor for prayer ... not because God dwells in an earthly place."48 In this instance, Augustine does include the "true worshippers" of John 4:23, but it is in a longer quotation of v. 21 and following, meaning that he does not emphasize it, as one will find also in his Questiones libri septem 5.10.1. ${ }^{49}$ Again, in his Sermo 53, Au-

45 Augustine, Serm. 21.2; Sancti Aurelii Augustini Sermones de uetere testamento, ed. by C. Lambot (CCL, 41), Turnhout, 1961, p. 277 [= NBA, 29.394]: “... quod auide manducaturi et bibituri sumus ..." For recent English translation see WSA, part III, vol. 2: Sermons (20-50) on the Old Testament, trans. E. Hill, Hyde Park, NY, 1990.

46 Augustine, Sermo 21.2; NBA, 29.396: "Ineffabile bonum, bonum beneficum, bonum bonorum omnium creatorem."

47 Augustine, Sermo 198aug.11 [= Mainz 62.11 = Dolbeau 26.11]; Augustin d'Hippone. Vingt-six sermons au peuple d'Afrique, ed. by F. Dolbeau, CÉASA, 147, Paris, 1996, p. 374 [= NBA, 35, Rome, 2002, p. 628]: “... omnis homo intus orat, cum bene orat ...” See WSA, part III, vol. 11: Newly Discovered Sermons, trans. E. Hill, Hyde Park, NY, 1997.

48 Augustine, Sermo 198aug.11; NBA, 35.630: "Veni ergo ad ecclesiam, ut excitetur feruo orandi ... non quia in loco terreno manet deus ...

49 Augustine, Quaestiones in Heptateuchum libri VII, ed. by J. Fraipont and D. De Bruyne (CCL, 33) Turnhout, 1958, p. 280 [= NBA, 11/2.1046]. 
gustine insists that no one think of God as physical. ${ }^{50}$ Rather, citing from Wisdom, "the souls of the righteous are the throne of wisdom" (Wis 1:4) and 1 Corinthians "you are God's holy temple" (1 Cor 3:17), Augustine reminds his flock that "God is Spirit, so worship him in Spirit and in truth" (John 4:24). The true worshippers are not mentioned.

Augustine's more systematic treatises bear similar results. In another question on Scripture, he does speak about the "worshippers" - without using the term adoratores or calling them 'true' (Diu. qu. 64.8). Instead, they are 'spiritual' (spirituales), and contrasted here with the earthly-minded (carnalibus). Elsewhere, in De Genesi ad litteram 12.7.18, Augustine explores the nature of human rationality (mens rationalis) and the "eye of the soul" (oculus animae), which is a rough-equivalent of the "image of God." ${ }^{11} \mathrm{He}$ then quotes four Pauline texts (Eph 4:23-24; $\mathrm{Col}_{3}$ :20; Rom 7:25; and Gal 5:17), and ends with a quotation from John 4:24, without mentioning the use of "true worshippers" in the preceding verse (John 4:23). The following section moves into yet another Pauline text, contrasting the spiritual and the terrestrial.

Finally, in two of Augustine's letters, he makes the same point of emphasis. In the second of these, he turns again to Paul's line, "who knows what is in a man, except his own spirit" (1 Cor 2:11), in a discussion of human beings as rational creatures. ${ }^{52}$

\subsection{Does 'Truth' Ever Appear in Augustine's Ecclesiology?}

Though we have seen that Augustine does not appear to emphasize 'truth' in his interpretation of John 4:23, the verse does appear with considerable frequency in Augustine's thought, and in particular within his In Iohannis euangelium tractatus and Enarrationes in Psalmos. In In Iohannis euangelium tractatus 3, for example, Augustine contrasts Christ with Lucifer (cf. Isa 14:12),

50 Augustine, Sermo 53.6.7; P. Verbraken, "Le Sermon 53 de saint Augustin sur les Béatitudes selon saint Mattieu," RBen, 104 (1994), pp. 19-33, at p. 24 [=NBA, 30/1.92], “... ut deum non cogites esse corporeum ... See WSA, part III, vol. 3: Sermons (51-94) on the Old Testament, trans. E. Hill, Hyde Park, NY, 1991.

Augustine, Gn. litt. 12.7.18; Sancti Aureli Augustini De Genesi ad litteram libri duodecim, ed. by J. Zyscha (CSEL, 28), Vienna, 1894, p. 389 [= NBA, 9/2.652]: “... ad quem pertinet imago et agnitio dei." See WSA, part I, vol. 13: On Genesis, trans. E. Hill, Hyde Park, NY, 2002.

Augustine, Epp. 92.5; Sancti Aureli Augustini Hipponiensis episcopi Epistulae, ed. by A. Goldbacher (CSEL, 34), Vienna, 1898, pp. 436-444 [= NBA, 21/2.800-802]; and 238.2.15; Sancti Aureli Augustini Hipponiensis episcopi Epistulae, ed. by A. Goldbacher (CSEL, 57), Vienna, 1911, pp. 533-556 [= NBA, 23.786]. For English translations, see WSA, part II, vol. 1: Letters 1-99, trans. R. Teske, Hyde Park, NY, 2001; and WSA, part II, vol. 4: Letters 211-270, trans. R. Teske, Hyde Park, NY, 2005. 
and remarks that the angel lost his splendor (tenebrosus factus) because he was not 'in the truth' (in ueritate). ${ }^{53}$ Augustine is citing John 8:44 here to make his point, and in In Iohannis euangelium tractatus 8, he repeats the same principle. Like the anonymous (Donatist) homilist above, Augustine links Christ with the truth: "Christ is the truth, meaning that in Christ, one accepts the 'whole truth': true Word, God equal to the Father, true soul, true flesh, true man, true God, true nativity, true passion, true death, true resurrection."54

Elsewhere, Augustine will make great effort to address the relation of the church to Christ, which is the move made above in the anonymous Vienna Collection's Sermo 16. In this instance, however, Augustine was preoccupied with making an anti-Manichaean argument, by insisting that Christ did indeed take on flesh as the Gospel accounts indicate. The same verse, John 8:44, appears in In Iohannis euangelium tractatus 42, in an extended discussion of sin and error as corruptions of truth. Yet at no turn of the argument does Augustine seem to speak of other self-identifying Christians as 'false believers', nor of his own people as the 'true church'. Thus, Augustine differs on at least one occasion in his interpretation of John 4:23-24. He would also on multiple occasions make different use of the saying of Cyprian, "nulla salus extra ecclesiam", however these various research trajectories are the substance of a much larger study beyond the present scope.

Thus, Augustine differs from the anonymous homilist on more than one occasion in his interpretation of John 4:23-24, as well as, perhaps, in his understanding of 'truth', and of the very meaning of Cyprian's theological and ecclesiological position of "nulla salus extra ecclesiam". The first observation suggests to me, first, that Augustine apparently belonged to a separate tradition - or 'sub-tradition', granting the over-arching regional character of Christian theology and biblical interpretation in late Roman North Africa - of interpreting the Gospel of John. Such a difference, apparently, may well have been determined by his Nicene-Catholic faith, but also by the influence of Platonism and anti-Manichaean dialectic. As the evidence presented above suggests, however, the anti-Donatist element is not to be overlooked, even when

\footnotetext{
53 Augustine, In Io. eu. tr. 3.7; NBA, 24/1.52.

54 Augustine, In Io. eu. tr. 8.5; NBA, 24/1.194: "Sic est autem ueritas Christus, ut totum uerum accipias in Christo. Verum Verbum, Deus aequalis Patri, uera anima, uera caro, uerus homo, uerus Deus, uera natiuitas, uera passio, uera mors, uera resurrectio."
} 
Augustine seems to correct a Donatist reading by seemingly downplaying its validity. Thus, second, Augustine may have sought to correct a prevailing Donatist reading of John 4:23 in particular, as examples from In Iohannis euangelium tractatus 15, other sermons, and Enarrationes in Psalmos illustrate. Though he does not quote a 'Donatist' preference in these contexts, Augustine has countered Donatist views on baptism and the Holy Spirit on multiple occasions in the previous tractates on John. Thus, I find Henry Chadwick's assessment convincing, when for example he writes, "The controversy with the Donatists revolves round the idea of the Church. For Augustine this is in its essence a united body, a universal and visible society or fellowship of baptized believers, and not only an earthly society." 55 As much as the Johannine ecclesiastical doctrine was compatible with either of these two options, I have sought to suggest in summary form how it was nevertheless put to use by both parties.

In this paper, I have tried to suggest in a necessarily compressed way something of how Sermo 37 of the anonymous Vienna Collection may serve as an entry point to discover a possible Donatist reading of John, as well as how its reading of John 4:23 differs from that of Augustine in a rather noticeable way. Yet rather than ultimately to disparage the former, I hope to have offered preliminary evidence that there may indeed have been a uniquely Donatist 'school' for interpreting John. Other citations in the collection such as the frequently cited John 5:14, "iam noli peccare", as well as other sources which contain possible evidence of pro-Donatist polemics, may well support this conclusion in subsequent research.

55 H. Chadwick, The Church in Ancient Society: From Galilee to Gregory the Great, Oxford History of the Christian Church, Oxford, 2001, pp. 391-392. 